Working Paper 2010:5

Department of Economics

Timing of death and the repeal of the Swedish inheritance tax

Marcus Eliason and Henry Ohlsson 
Department of Economics

Uppsala University

P.O. Box 513

SE-751 20 Uppsala

Sweden

Fax: $+{ }_{4} 6184711478$
Working paper 2010:5

March 2010

ISSN $1653-6975$

Timing of DeATH AND the RePeAl of THe Swedish

INHERITANCE TAX

Marcus Eliason and Henry Ohlsson

Papers in the Working Paper Series are published on internet in PDF formats.

Download from http://www.nek.uu.se or from S-WoPEC http://swopec.hhs.se/uunewp/ 


\title{
Timing of death and the repeal of the Swedish inheritance tax*
}

\author{
Marcus Eliason Henry Ohlsson
}

March 26, 2010

\begin{abstract}
Does taxation affect the timing of death? This is an interesting example of how behavior might be affected by economic incentives. We study how two changes in Swedish inheritance taxation 2003/04 and 2004/05 have affected mortality during the turns of the years. Our first main result is that deceased with estates taxable for legal heirs were 10 percentage points more likely to have died on New Year's Day 2005, from when the inheritance tax was repealed, rather than on New Year's Eve 2004, compared to deceased without taxable estates for legal heirs. The second main result is that deceased with estates taxable for a married spouse were 12 percentage points more likely to have died on New Year's Day 2004, from when the inheritance tax between spouses was repealed, rather than on New Year's Eve 2003, compared to deceased without taxable estates for a married spouse.
\end{abstract}

Keywords: behavioral response to taxes, timing of death, estate tax, inheritance tax, tax avoidance, mortality

EconLit subject descriptors: H240, H310, I120

Marcus Eliason, Institute of Labour Market Policy Evaluation (IFAU), Uppsala, Sweden and Centre for European Labour Market Studies (CELMS), University of Gothenburg, Sweden Henry Ohlsson, Department of Economics, Uppsala University and

Uppsala Center for Fiscal Studies (UCFS), Department of Economics, Uppsala University, Sweden

Corresponding author:

Henry Ohlsson, Department of Economics, Uppsala University, Box 513, SE-751 20 Uppsala, Sweden, email<henry.ohlsson@nek.uu.se>, phone +461847111 04, fax +4618471 1478

*We are grateful to Cecilia Halling and Erik Ohlsson for excellent research assistance. Financial support from the Jan Wallander and Tom Hedelius Foundations and helpful comments from Mikael Elinder, Håkan Selin, Daniel Waldenström, and seminar participants at Royal Holloway and Uppsala are gratefully acknowledged. Some of the work was done when Ohlsson enjoyed the hospitality of LEM, Université Panthéon-Assas, Paris II and Freie Universität Bozen. 


\section{Introduction}

Economic incentives more or less affect the behavior, and timing of behavior, for each of us, each and every day. But is it reasonable to assume that even the timing of death can be affected? Kopczuk and Slemrod (2003) and Gans and Leigh (2006) raise this question. They investigate whether death responds to changes in estate and inheritance taxes. Although this may seem farfetched at first, both papers report evidence that this might be the case.

Kopczuk and Slemrod (2003) study a series of changes of the US estate tax. They present evidence that potential tax savings from estate tax reforms do increase the probability of dying in the lower tax regime. Gans and Leigh (2006) study the 1979 inheritance tax repeal in Australia. They estimate that about 5 percent of the deaths were shifted from the week preceding the tax repeal to the following week. They conclude that more than half of those who would have paid the tax the last week avoided the tax.

The Swedish Parliament decided in December 2003 to repeal the inheritance tax between married spouses and cohabiting spouses from January 1, 2004. The following December, Parliament decided to repeal the inheritance tax altogether from January $1,2005 .^{1}$ This provides a unique opportunity to study two natural experiments, an expected inheritance tax repeal for married spouses and cohabiting spouses and an expected complete inheritance tax repeal. We would expect deaths to be postponed if people try to avoid taxes.

In Eliason and Ohlsson (2008), we study aggregate daily mortality during the time periods around these repeals of the Swedish inheritance tax. Our main result is that mortality decreased by 17 percent the day before the expected tax repeals began. In the data set used in that paper we did not, unfortunately, have information on whether the heirs of the deceased were subject to inheritance taxation or not.

This is remedied here. We have constructed a data set based on the estate reports of all deceased in Sweden New Year's Eve and New Year's Day 2003/04 and 2004/05. The number of deceased was 1,132 during the four days in question. Our objective is to study if dying on New Year's Day was more likely than dying on New Year's Eve among those with tax incentives to do so. The crucial variables constructed concern whether the estate was large enough to have made those inheriting paying inheritance taxes if the death occurred before the repeal of the inheritance tax. We construct an indicator for estates resulting in taxable inheritances for legal heirs and another indicator for estates resulting in taxable inheritances for married spouses. ${ }^{2}$

\footnotetext{
${ }^{1}$ Parliament later passed a law on inheritance tax exemption for the period December 17-31, 2004. The reason was the large number of Swedes killed in the Asian Tsunami December 26, 2004. 527 Swedish residents have been identified and confirmed deceased, while 16 are still missing. The inheritance tax exemption was not known or expected around the New Year 2004/05.

${ }^{2}$ We will use the term "taxable estate" as a compact way of referring to estates that were large enough to have made those inheriting paying inheritance taxes had the death occurred before the repeal of the inheritance tax.
} 
Our first hypothesis is that a legal heir's tax liability affected the timing of death during the New Year holiday 2004/05 as the inheritance tax for legal heirs was expected to be repealed from January 1, 2005. We do not expect, on the other hand, that this affected the timing of death during the New Year holiday 2003/04 as there were no inheritance tax changes affecting legal heirs at that time.

Our second hypothesis is that a married spouse's tax liability affected the timing of death during the New Year holiday 2003/04 as the inheritance tax for spouses was repealed from January 1, 2004. We do not expect, on the other hand, that this affected the timing of death during the New Year holiday 2004/05 as there were no inheritance tax changes affecting spouses at that time.

The hypotheses are borne out by the data. Our first main result is that deceased with estates taxable for legal heirs were 10 percentage points more likely to die on New Year's Day 2005, when the inheritance tax was repealed, rather than on New Year's Eve 2004, compared to deceased without taxable estates for legal heirs. The second main result is that deceased with estates taxable for a married spouse were 12 percentage points more likely to die on New Year's Day 2004, when the inheritance tax between married spouses was repealed, rather than on New Year's Eve 2003, compared to deceased without taxable estates for a married spouse.

The rest of the paper is structured as follows: Section 2 discusses the potential means by which the timing of death might be affected. In Section 3, we present the data and how the data set was constructed. An appendix gives more detail on this. We also present some descriptive results in this section. Section 4 presents our econometric evidence. The main specifications are supplemented by sensitivity analyses. Section 5 concludes.

\section{The potential means by which the timing of deaths can be postponed}

At first it might seem farfetched that economic incentives, such as a repeal of the inheritance tax, will or even can affect the timing of death. There are, however, several potential means by which the timing of deaths can be postponed. First, it is commonly believed that terminally ill people to some extent are able to hold on or give up on life. A series of articles have investigated mortality patterns around symbolically meaningful occasions such as birthdays and religious holidays. Phillips and Smith (1990) showed that mortality among Chinese dipped in the week before the Harvest Moon Festival and peaked by the same amount in the week after. The Smith (2004) re-examination, however, does not support this finding. Idler and Kasl (1992) found that some elderly Christians and Jews were able to postpone their deaths until after the celebration of religious holidays. A similar dip-peak patter of mortality among Jews was found around the Jewish holiday of Passover in Phillips and King (1988). Young and Hade (2004) investigated cancer deaths around holidays and birthdays, but failed to provide evidence that cancer patients were able to postpone death until after such events. A recent study (Panesar and 
Goggins, 2009), however, found significantly fewer cancer deaths before than after the celebration of four important holidays among men, but not women, in Hong Kong. Hence, it seems that the scientific evidence on whether humans really have the ability to intentionally influence the timing of death via psychosomatic processes is contradictory.

Modern medical technology, however, certainly allows physicians to postpone patients' deaths in many circumstances. An increasing number of deaths are preceded by medical end-of-life decisions such as whether to withhold or withdraw life support (e.g., ventilator support, antibiotic therapy, and artificial hydration and nutrition), and in palliative care whether to alleviate pain or other symptoms by increasing drug doses so that hastening of death by respiratory depression is a possible or even expected side effect.

van der Heide et al. (2003) found that in Sweden 36 percent of all deaths are preceded by end-of-life decisions while in Switzerland the same figure is as high as 51 percent. In Sweden almost all these decisions concerned alleviation of pain and symptoms with possible life shortening effect ( 21 percent) or non-treatment decisions (14 percent). In a majority of these cases ( 71 and 59 percent, respectively) the estimated shortening of life was less than a week. The same study showed that if the patient was competent the decision was discussed either with the patient him/-herself in 47 percent of the cases, while if the patient was incompetent the share decreased to 42 percent. Another survey (Miccinesi et al., 2005) showed that 88 percent of the responding physicians thought that physicians should comply with patients' requests to withhold (or withdraw) life-sustaining treatment and if the patient was incompetent 41 percent thought that relatives should be allowed to decide on behalf of the patient. Thus, there seem to be at least some opportunity for either the patient or the relatives (i.e., heirs) to advocate initiation or withholding of life support or more aggressive treatment. A sense of self-perceived burden to others has in several studies been found to be a concern underlying many requests of no treatment or death-hastening acts. ${ }^{3}$ The knowledge about the monetary reward to the heirs implied by the tax saving may reduce such feelings of becoming a burden to others.

Another potential mean by which the timing of death can be postponed, in cases where the deceased in fact died before the turn of the year, is manipulation of death certificates. There are, however, a number of complicating regulations regarding the issuing of death certificates. The death certificate should be issued by the physician who declares the person dead. The physician may not be a relative, or close in any other way, to the deceased. The physician is required to examine the body unless either the death was expected, in which case an examination by a nurse is sufficient, or if the physician had examined the deceased shortly enough before the death to reliably exclude the possibility that a forensic autopsy is warranted. The death certificate should then be submitted to the Tax Agency no later than the first workday following the declaration of the death. As with all legal documents

\footnotetext{
${ }^{3}$ See McPherson et al. (2007) for a review.
} 
there is likely to be at least some scope for manipulation. This is especially so considering that a review of the handling of death certificates has been warranted since "too often" the death certificates are not submitted in time or are either incomplete or incorrectly completed (SOU, 2001).

A final possibility is postponement of suicides. There is evidence that suicide mortality is, in fact, affected by the suicide exclusion on individual life insurances. Tseng (2004) found that suicide rates were four times higher after the two-year exclusion period. ${ }^{4}$ However, due to the small share of all deaths being suicides this could not be a principal mean by which deaths are postponed.

Our empirical analysis will not be able to discriminate between these possible means, by which the timing of death can be postponed, but for how long each of them is likely to postpone death may at least give some guidance.

\section{Data and descriptives}

The objective of this section is, first, to present how we have calculated the crucial variables for the analysis, i.e., whether the estates of the deceased were large enough to have generated liabilities to pay inheritance taxes. This depends on both civil law and tax law. We will only give very general descriptions of the main legal aspects with a focus on what is important for calculating the crucial variables. There are, as always in legal matters, many exceptions, special treatments, etc., but presenting all this is beyond the scope of the paper. ${ }^{5}$ Finally, we will present and discuss some descriptive statistics and results.

\subsection{The estate of the deceased}

A first issue is to determine the size of the estate of the deceased. The marital status of the deceased is crucial for calculating this.

Married or cohabiting. For the deceased who were married, matters are complicated by the existence of separate and joint property. Joint property is default for married spouses. There may, however, exist prenuptial agreements and similar documents defining separate property. The estate of a married deceased consists of the separate property and half the joint property. The estate reports contain enough information to calculate this and we have adjusted the estate accordingly.

Similar problems arise for those who cohabited without being married. An important difference compared to married spouses, however, is that separate property is the default for cohabiting spouses. Exceptions to this are assets and debts connected to joint housing which are considered as joint by default. This includes real housing property, housing (mortgage) debt, furniture, household property etc. The

\footnotetext{
${ }^{4}$ It is noted, however, that since suicides during the exclusion period might have been disguised as accidents this figure might have been overestimated.

${ }^{5}$ We have mainly relied on Brattström and Singer (2007) and Waller (2000), that only are available in Swedish.
} 
estate of a cohabiting deceased consists of the separate property and half the joint housing property. The estate reports contain enough information to calculate this and we have adjusted the estate accordingly.

Cohabiting without being married is, however, not an exclusive marital status. Deceased with a marital status as as widowed, unmarried, or divorced may-as discussed below-be cohabiting.

Widow(er). For deceased widow(er)s, the estates might include property of the first deceased spouse, i.e., property that was not transferred to the heirs at the time of the first spouse's death. These funds were, at the time, left at the free disposal of the surviving spouse as an inheritance.

It is seldom the case that this happens. But when it does, this property does not really belong to the deceased. From the point of view of the heirs, the actual estate of the deceased and the estate of the first deceased spouse give rise to separate inheritances, in most cases an inheritance from the father and an inheritance from the mother. Inheritance taxation also considered these transfers as separate inheritances.

If there is no separate property and nothing was distributed when the first spouse died, then the estate of a widowed deceased is half the total property. The other half is considered to be the estate of the first deceased spouse. Unfortunately, estate reports do not always contain enough information about the estate division after the death of the first spouse. It has, therefore, not been possible for us to adjust for this-see, however, the sensitivity analysis in Section 4.2.

Unmarried or divorced. It is straightforward to calculate the estates of unmarried and divorced deceased provided that they did not have a cohabiting spouse. The reason is that we are sure that there is no property of a surviving spouse or a previously deceased spouse.

Table 1 presents some descriptive statistics for the deceased. ${ }^{6}$ The estates of those who died on New Year's Day are larger than the estates of those who died the day before. Looking at the medians rather than the means, to avoid the impact of extreme values, the difference is SEK 28,000 in 2003/04 and SEK 55,000 in $2004 / 05 .^{7}$ The latter difference might be biased upwards somewhat as there are some changes in the principles by which some assets are valued from 2005 . We will return to this in the sensitivity analysis reported in Section 4.2.

As is clear from the table, there are no corresponding differences in income. The differences in age and the number of children are also negligible. The share of women who died on New Year's Day is lower than the day before while the share of married is higher.

\footnotetext{
${ }^{6}$ The deceased in the Asian Tsunami all have December 26, 2004 as date of death and are, therefore, not included in these samples.

${ }^{7}$ The SEK/USD and SEK/EUR exchanges rates were roughly 7.35 and 9.15 in 2004.
} 
Table 1: Some descriptive statistics for the deceased.

\begin{tabular}{|c|c|c|c|c|}
\hline & \multicolumn{2}{|c|}{ partial repeal } & \multicolumn{2}{|c|}{ complete repeal } \\
\hline & $\begin{array}{c}\text { New Year's Eve } \\
2003\end{array}$ & $\begin{array}{c}\text { New Year's Day } \\
2004\end{array}$ & $\begin{array}{c}\text { New Year's Eve } \\
2004\end{array}$ & $\begin{array}{c}\text { New Year's Day } \\
2005\end{array}$ \\
\hline estate, SEK, mean & $\begin{array}{c}269,500 \\
(399,400)\end{array}$ & $\begin{array}{c}391,800 \\
(1,868,700)\end{array}$ & $\begin{array}{l}322,200^{a} \\
(646,200)\end{array}$ & $\begin{array}{l}439,300^{b} \\
(882,000)\end{array}$ \\
\hline median & 140,800 & 168,500 & $133,900^{a}$ & $188,600^{b}$ \\
\hline income $^{c}, \mathrm{SEK}$, mean & $\begin{array}{l}140,400 \\
(85,300)\end{array}$ & $\begin{array}{c}280,500 \\
(2,284,700)\end{array}$ & $\begin{array}{l}147,600 \\
(91,200)\end{array}$ & $\begin{array}{c}169,200 \\
(192,800)\end{array}$ \\
\hline median & 129,600 & 129,000 & 126,100 & 133,600 \\
\hline age, years, mean & $\begin{array}{c}78.2 \\
(12.9)\end{array}$ & $\begin{array}{c}78.8 \\
(13.5)\end{array}$ & $\begin{array}{c}79.6 \\
(14.0)\end{array}$ & $\begin{array}{c}77.9 \\
(16.0)\end{array}$ \\
\hline median & 82 & 82 & 83 & 82 \\
\hline $\mathrm{n}$ of children, mean & $\begin{array}{c}1.74 \\
(1.59)\end{array}$ & $\begin{array}{c}1.71 \\
(1.40)\end{array}$ & $\begin{array}{l}1.85 \\
(1.47)\end{array}$ & $\begin{array}{c}1.76 \\
(1.40)\end{array}$ \\
\hline median & 2 & 2 & 2 & 2 \\
\hline woman, \% & 54.2 & 49.0 & 51.1 & 48.6 \\
\hline married, $\%$ & 31.9 & 35.4 & 32.0 & 33.9 \\
\hline unmarried, $\%$ & 15.0 & 12.1 & 12.5 & 12.9 \\
\hline divorced, $\%$ & 16.2 & 12.7 & 12.9 & 11.2 \\
\hline widow(er), \% & 36.9 & 39.8 & 42.6 & 42.0 \\
\hline cohabiting, $\%$ & 5.8 & 4.5 & 2.2 & 3.1 \\
\hline will, \% & 26.2 & 25.2 & 19.8 & 21.0 \\
\hline $\mathrm{n}$ of observations & 260 & 314 & 272 & 286 \\
\hline
\end{tabular}




\subsection{Defining taxable estates}

Knowing the size of an estate is not enough to determine whether there would have been taxes levied on it as Sweden taxed inheritances, not estates. We, therefore, need to know the estate division before it is possible to determine whether there would have been taxes levied on the estate or not.

Estate division. There are three classes of heirs according to the intestate succession scheme in Swedish civil law. The first class consists of the children of the deceased and their descendants-the direct heirs. There is one lot per child. 77.2 percent of the deceased in our sample had heirs in this class. In other words, as many as almost a quarter of the deceased did not have children.

If there are no heirs in the first class the estate is divided among those in the second class. The second class consists of the parents and their descendants, i.e., siblings, nieces/nephews and their descendants. There is one lot per parent if the parents are not both deceased. In our sample, 16.9 percent of the deceased had heirs belonging to the second class while they did not have heirs belonging to the first class.

If there are no heirs in the first class and the second class the estate is divided among those in the third class. The third class consists of the grandparents and their children. First cousins and their descendants, however, are not legal heirs. There is one lot per grandparent if the grandparents are not all deceased. Very few estates in our sample, 0.2 percent, belong to this class.

There is, however, an important exception to these principles on how to divide an estate. This occurs when the deceased was married and leaves a surviving spouse. A surviving spouse has priority over heirs in all three classes. ${ }^{8}$ If there are heirs in any of the first two classes, the inheritance will instead be at the free disposal of the surviving spouse. The heirs will get their inheritances when the surviving spouse dies. If there are no heirs in the first two classes, the inheritance will be at the full ownership of the surviving spouse.

If there are no heirs in any of the three classes and no surviving married spouse, the estate will be transferred to The Swedish Inheritance Fund. There are 37 deceased in our sample, or 3.3 percent, without heirs in any of the three classes and without a married spouse.

The default estate division according to the intestate succession scheme in the civil law can be circumvented by writing a will. If there are heirs in any of the two first classes, it is possible to freely bequeath half the estate. If there are only heirs in the third class or no heirs at all in any of the classes the whole estate can be bequeathed freely.

About 23 percent of the deceased have written wills. There is some variation in this share between the days studied, as is clear from Table 1. The wills can be of any type and may not have to do with estate division at all. Some stipulate unequal sharing between heirs, others stipulate that property received should be separate

\footnotetext{
${ }^{8}$ This was introduced in the new Marriage Code in 1988.
} 
Table 2: Incidence of written wills.

\begin{tabular}{lc}
\hline deceased with: & share with written wills, \% \\
\hline direct heirs, class 1 & 17.2 \\
legal heirs, class 2 & 38.4 \\
a married spouse but no legal heirs & 48.3 \\
no married spouse and no legal heirs & 64.9 \\
& \\
a married spouse & 25.1 \\
a cohabiting spouse & 45.4 \\
\hline
\end{tabular}

property. Many wills are joint wills and concern the property rights of a surviving spouse. Some wills are recent, some old.

The share of deceased who left a will is increasing with the lack of close relatives. Only 17 percent of the deceased with children have written wills compared to 65 percent of those not married and without legal heirs, see Table 2. Wills are also more common among deceased with a cohabiting spouse compared to those with a married spouse. This might be a response to the lower legal protection of a surviving cohabiting spouse.

For the hypotheses studied in this paper it is not clear that all the economic agents who could have made decisions affecting the timing of death knew about the existence and the content of a will. There are many elements of uncertainty surrounding the transfer of an estate. The exact net worth of the estate is not known with certainty until the estate report is completed. It is also an option, not an obligation, to accept an inheritance. It is not clear in advance whether heirs will accept the inheritance or not.

Heirs may have engaged in tax avoiding activities, but it is not clear whether they did. And to what extent do the agents know the subtleties of civil and tax law? In general the information sets of those involved are not obvious. We do simply not know who knew what and when.

We have, therefore, decided to rely on the basic assumption that estates were divided according to the default principles in civil law (intestate succession). These principles, at least, are reasonable to assume were known to all those involved. This assumption also makes it impossible to study taxable estates for a cohabiting spouse. A bequest in a will is, in practice, necessary for a cohabiting spouse to be affected by the tax repeal.

Inheritance taxes. There was a basic exemption of SEK 70,000 for a child inheriting a parent ( $\approx$ USD 9,500 or EUR 7,700 in 2004 values). This exemption level applied to all heirs in the first class. For a married spouse inheriting the ex- 
emption was SEK 280,000, the same exemption level also applied for a cohabiting spouse. The basic exemption for all other heirs was SEK 21,000.

There were three tax brackets for the taxable inheritance amount: 10 percent, 20 percent, and 30 percent. The top marginal tax rate for children was for inherited amounts in excess of SEK 670,000 ( $\approx$ USD 91,000 or EUR 73,000 in 2004 values). For spouses the top marginal rate started to apply for inherited amounts in excess of SEK 880,000. The corresponding amount for all other legal heirs was SEK 161,000 .

We have constructed two independent indicators for estates giving rise to inheritances that would have been taxed had the inheritance taxation not been repealed. The first indicator is for estate taxable for legal heirs. This variable takes the value one for estates larger than SEK 70,000 per child (the basic exemption level) if there were heirs in the first class. The dividing value for estates with heirs in the second or third class is SEK 21,000 per lot. The indicator takes the value zero if the lots are below SEK 70,000 and SEK 21,000, respectively.

The second indicator is for estates taxable for a married spouse of the deceased. This variable takes the value one for deceased leaving a married spouse and an estate larger than SEK 280,000 and takes the value zero otherwise. The estates taxable for a married spouse are fewer and larger than the estates taxable for legal heirs. The conditional medians are SEK 495,000 for the former and SEK 388,000 for the latter.

It should be stressed that what was important for inheritance taxes was your relationship to the deceased, not whether you inherited according to the default rules or because of a bequest in a written will.

The correlation between the indicator for estate taxable for legal heirs and the indicator for estates taxable for a married spouse is 0.35 for the complete sample. It is, of course, considerably higher, 0.63 , for the sub-sample of married deceased.

\subsection{Descriptive results}

The two repeals of the inheritance tax created incentives to postpone death. This concerned estates taxable for married spouses during the New Year holiday 2003/04. The following New Year holiday there were analogous incentives for estates taxable for legal heirs. The incentive structure was as follows:

\begin{tabular}{lcc|cc}
\hline & \multicolumn{2}{c|}{ partial repeal } & \multicolumn{2}{c}{ complete repeal } \\
& $\begin{array}{l}\text { New Year's Eve } \\
2003\end{array}$ & New Year's Day & New Year's Eve & New Year's Day \\
& liable to pay tax & liable to pay tax & liable to pay tax & tax repealed \\
$\begin{array}{l}\text { estate taxable for } \\
\text { legal heirs }\end{array}$ & no tax incentive to postpone death & tax incentive to postpone death \\
\hline $\begin{array}{l}\text { estate taxable for } \\
\text { married spouse }\end{array}$ & liable to pay tax $\quad$ tax repealed & tax repealed & tax repealed \\
& tax incentive to postpone death & no tax incentive to postpone death \\
\hline
\end{tabular}


Figure 1: Deceased on New Year's Day during the New Year holiday, deviation from a 50-50 split.

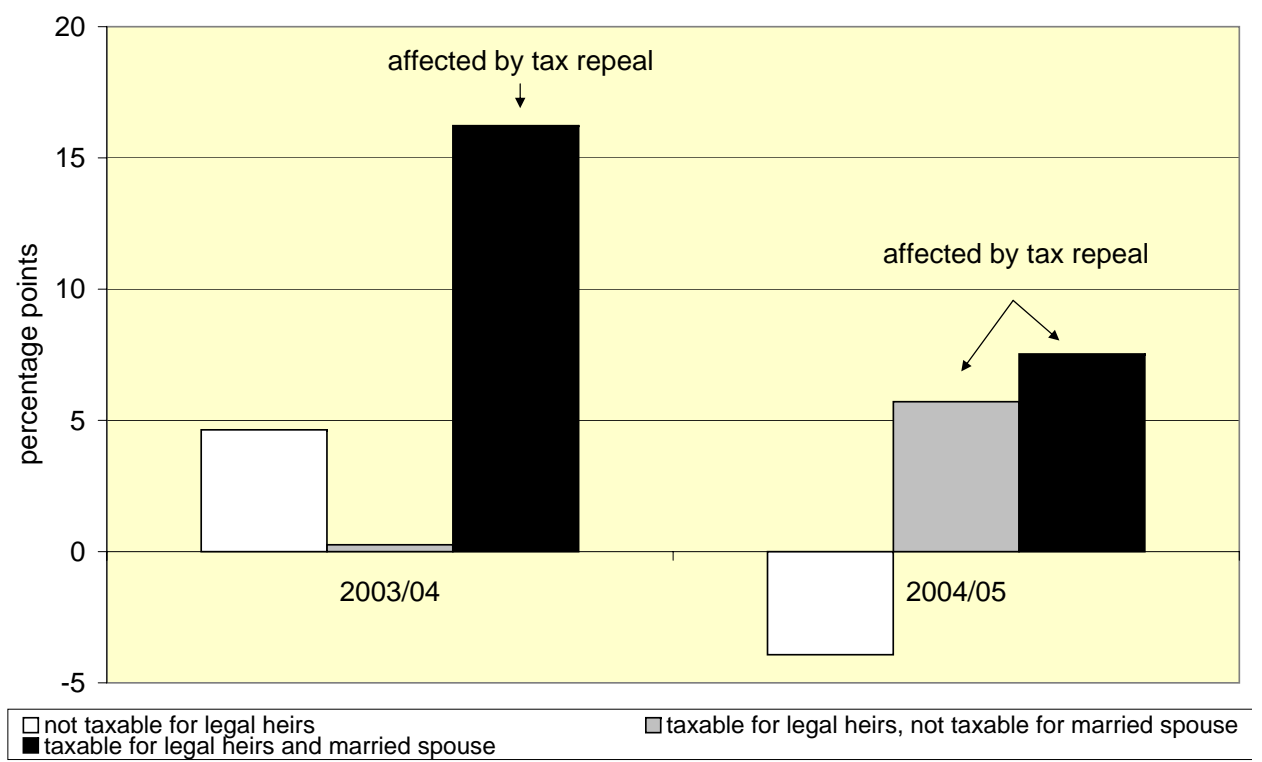

Figure 1 presents how dying on New Year's Day rather than on New Year's Eve varies depending on whether the estate is taxable for legal heirs and a married spouse. The figure shows the deviation on New Year's Day from a 50-50 split between the two days. Almost 55 percent of the deceased during the New Year holiday 2003/04 without an estate taxable for legal heirs died on New Year's Day, while 45 percent died the day before. ${ }^{9}$ The deviation from a $50-50$ split is, therefore, almost 5 percent. This is represented by the white bar to the left in Figure 1. There were no tax incentives for the deceased without an estate taxable for legal heirs to postpone death to New Year's Day as there were no taxes levied on the inheritances from their estates.

It is also clear from the figure that the deceased during the New Year holiday 2003/04 with an estate taxable for legal heirs, but not taxable for a married spouse, were as many New Year's Eve as New Year's Day. There existed no tax incentives to postpone death to New Year's Day for these deceased. Inheritance taxes would have been levied if legal heirs inherited regardless of the day of death. And regardless of the day of death, no inheritance taxes would have been levied if a married spouse inherited.

But for those with estates taxable for a married spouse there were tax incentives to postpone death to New Year's Day. Close to two thirds of the deceased during

\footnotetext{
${ }^{9}$ Very few of these estates were taxable for a married spouse, but not for legal heirs, as this requires that there are many legal heirs. For instance, a SEK 300,000 estate will not be taxed if there are five children who inherit but it will be taxable for a married spouse.
} 
the New Year holiday 2003/04 with an estate taxable for a married spouse (and taxable for legal heirs) died on New Year's Day, while only a third died the day before. This strongly suggests that tax incentives affected the timing of death.

Let us now turn to the New Year holiday 2004/05 when the inheritance tax was repealed altogether. Figure 1 shows that fewer than 50 percent of the deceased during the New Year holiday 2003/04 without an estate taxable for legal heirs died on New Year's Day. Almost 54 percent died the day before. There existed no tax incentives to postpone death to New Year's Day for these deceased as there were no taxes levied on the inheritances from their estates.

On the other hand, there were tax incentives to postpone death for those with estates taxable for legal heirs, regardless of whether the estate was taxable for a married spouse. It is clear from the figure that considerably more than half of the deceased during the New Year holiday 2004/05 with an estate taxable for legal heirs died on New Year's Day. The shares were almost 56 percent for deceased with estates not taxable for a married spouse and almost 58 percent for deceased with estates taxable for a married spouse. This strongly suggests, once again, that tax incentives affected the timing of death.

\subsection{Discussion}

The descriptive results reported in subsection 3.3 strongly indicate that deaths were more likely to occur on New Year's Day, rather than on New Year's Eve, among those who has tax incentives to postpone their death. An emerging question, however, is whether such an effect may have other explanations than that some deaths were postponed to escape inheritance taxes? For example, New Year's Day has been suggested to be an important milestone which in itself could affect peoples will to postpone death. Shimizu and Pelham (2008) found that Americans are more likely to die shortly after, than before, the turn of the year and especially on New Year's Day. ${ }^{10}$

To test whether this is true also for Swedes we have collected aggregate daily mortality data for the New Year holidays 1947/48-2005/06. Figure 2 reports the general mortality pattern during the New Year holiday during almost 60 years. The average share deceased on New Year's Day during the New Year holiday is 50.18 percent, the standard error of mean is 0.29 . The standard deviation of the share is 2.25 percentage points.

The share for the partial repeal New Year holiday 2003/04 was 54.7 percent, see the filled square in Figure 2. This is the highest share during the whole period. The share for the following New Year holiday, with the complete repeal, was 51.2 percent, see the second filled square. The millennium changeover, on the other hand, had a share of only 48.2 percent, see the square in Figure 2. This is contrary to the millennium effect found for other countries.

\footnotetext{
${ }^{10}$ There is some empirical evidence that the millennium changeover had an a larger death deferral effect than other turns of the year, see Gans and Leigh (2009) and Shimizu and Pelham (2008).
} 
Figure 2: Deceased on New Year's Day during the New Year holiday, deviation from a 50-50 split, 1947/48-2005/06

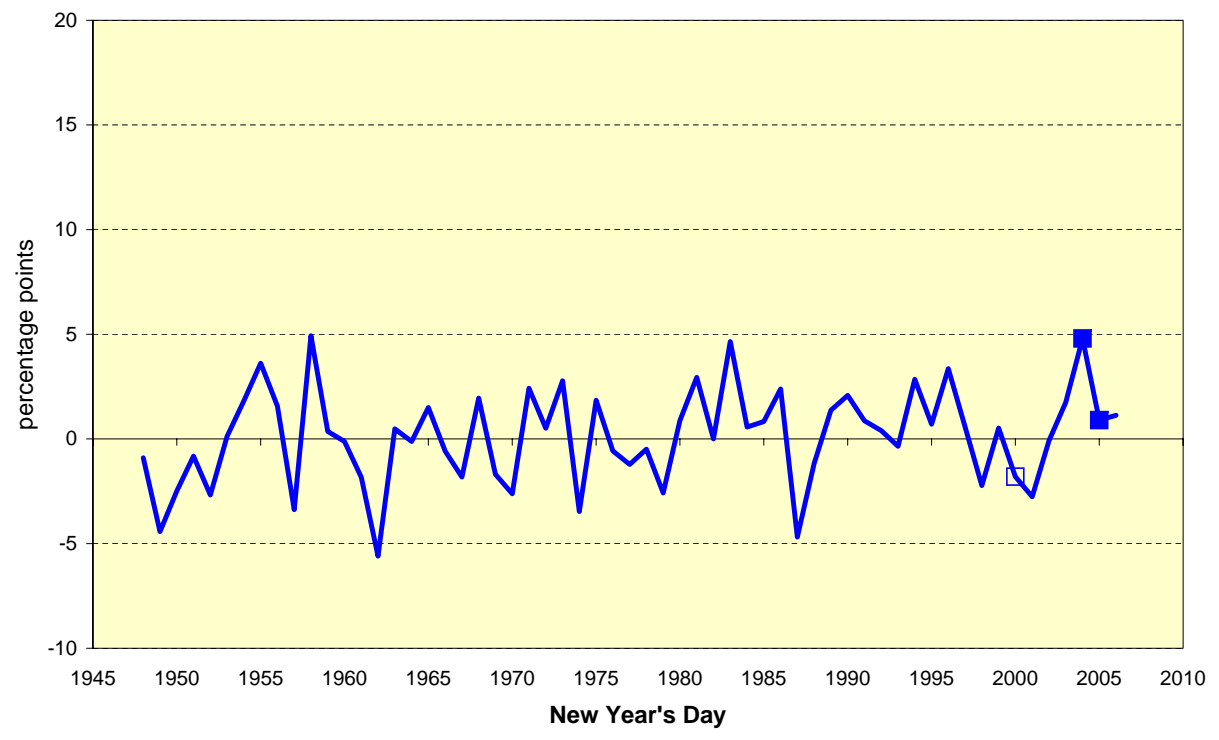

The general mortality pattern does not seem to vary over the New Year holiday. This is promising. We believe that this shows that concerns that other mechanisms, than tax incentives, drive any findings of a death deferral effect, can be played down somewhat. It is, however, still possible that there exist different mortality patterns for various socioeconomic groups that are correlated with the incidence and amount of taxable estates.

A first suspect might be fluctuations in temperature. There is, however, conflicting evidence on whether the impact of cold weather is modified by socioeconomic variables. ${ }^{11}$ A recent study (Rocklöv and Forsberg, 2008) on the effects of temperature on mortality in Stockholm showed no cold spell effects in addition to a cumulative effect of 0.7 percent per ${ }^{\circ} \mathrm{C}$ decrease. Moreover, they found, opposite to the mortality effects of heat, a delayed effect of cold. The latter makes it practically impossible to control, in any sensible way, for the impact of temperature fluctuations on mortality from one day to another. We have, nonetheless, collected temperature data for the New Year holidays we study. This did not reveal any extreme temperatures or large temperature fluctuations. The average temperature in Sweden's three largest cities (i.e., Stockholm, Gothenburg, and Malmö), for example, was $-4.5{ }^{\circ} \mathrm{C}$ both New Year's Eve and New Year's Day 2003/04. ${ }^{12}$ The average temperatures the following New Year's Eve and New Year's Day were

\footnotetext{
${ }^{11}$ See, for example, Donaldson and Keatinge (2003), Maheswaran et al. (2004), and Rau (2004).

${ }^{12}$ Almost 40 percent of Sweden's population reside in the three metropolitan areas surrounding these cities.
} 


\section{$2.5^{\circ} \mathrm{C}$ and $1.9^{\circ} \mathrm{C}$.}

A second suspect might be alcohol-related mortality during the holiday. This we cannot observe. But given that any such pattern would be the same from year to year it can implicitly be tested, since the inheritance tax was repealed in two steps affecting different groups in each step.

If those with estate taxable for legal heirs postpone death during the New Year holiday 2004/2005, i.e., those with tax incentives to postpone death, would be driven by anything else than the tax incentive, we would expect a similar postponement effect for this group also during the New Year holiday 2003/04 when there were no tax incentives. In the same way, if we find a postponement effect among the deceased with a taxable estate for a married spouse during the New Year holiday 2003/04, when there were tax incentives to postpone death, but that this does not depend on tax incentives, we would expect to also find a similar effect the following New Year holiday, when there were no tax incentives.

If, on the other hand, there are no such effects for the years when there were no tax incentives to postpone death, we can be reasonable certain that the results are not driven by differences in alcohol-related mortality between various socioeconomic groups or any other mechanism affecting mortality in the same way each New Year holiday. Hence, we will argue that any death deferral effects found here, in accordance with our hypotheses, are driven by the tax incentives.

\section{Econometric evidence}

\subsection{Main estimations}

Table 3 reports the results from our main estimations of probit models for the probability of dying on New Year's Day rather than on New Year's Eve. We restrict the sample to adults, i.e., those 18 years and older. The first three columns in the table report estimations concerning the New Year holiday 2003/04. It is clear that gender, marital status, and income are not significantly associated with the day of death. ${ }^{13}$

Some of the age indicators have significant coefficients. Those in the youngest age group and those in the age group of 80-89 years are more likely to have died on New Year's Day as compared to the reference group aged 70-79 years.

\footnotetext{
${ }^{13} \mathrm{We}$ have also tried to separate income into employment income, business income, and capital income. This does not make any difference. The indicator of the existence of a written will is not significant either.
} 


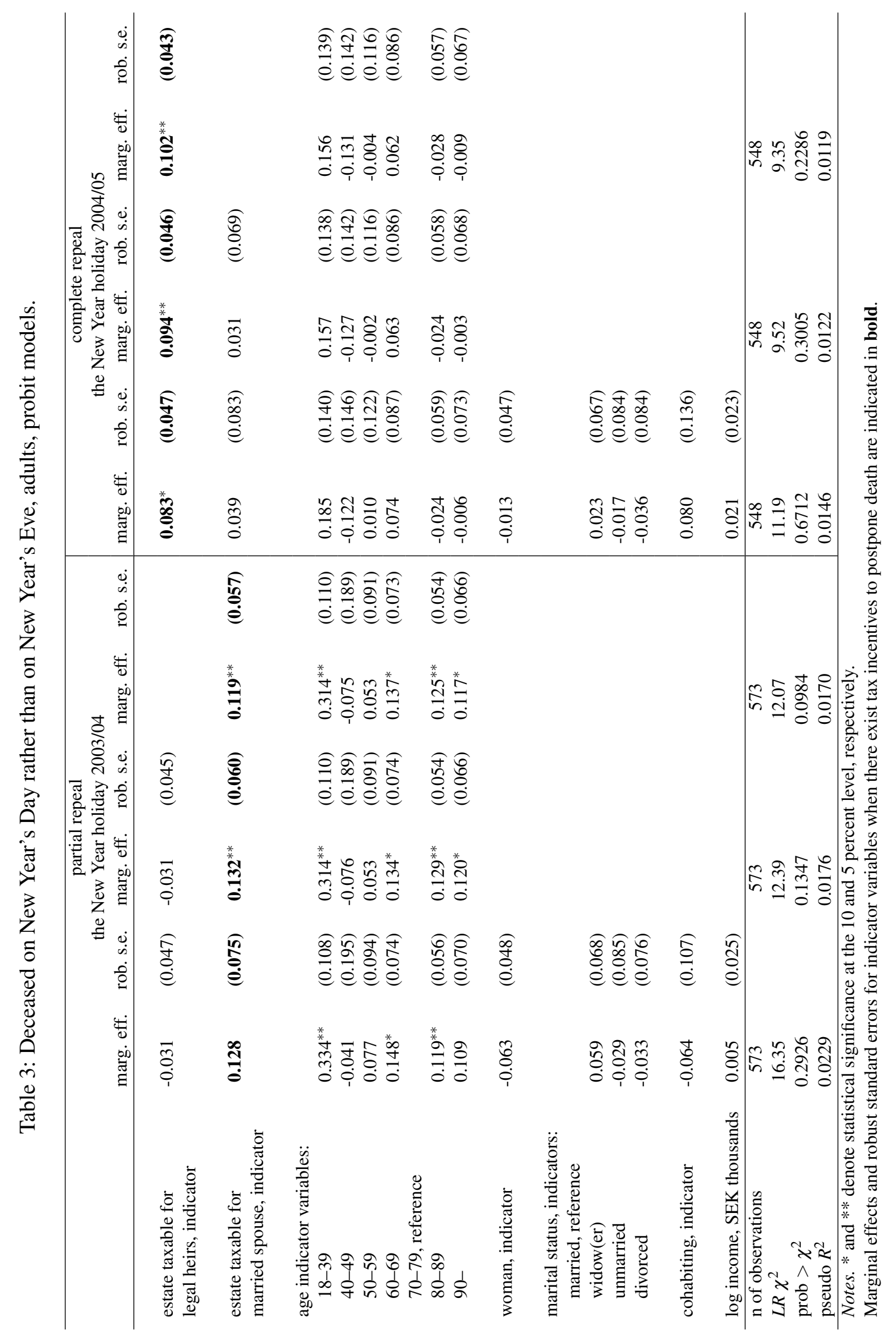


The key variables, however, are the indicator for estates large enough to be taxable for married spouses and the indicator for estates large enough to be taxable for legal heirs. During the New Year holiday 2003/04, the first is expected to cause deaths to be postponed because of tax incentives. The second is expected to have no impact as there were no tax incentives to change the timing of death. This is why it is excluded in the most parsimonious specification. The point estimates suggest that the likelihood of dying on New Year's Day, rather than on New Year's Eve, is about 12 percentage points higher among those with estates large enough to be taxable for a married spouse compared to the others.

The last three columns in the table concern the New Year holiday 2004/05. It is also here clear that gender, marital status, and income are not significantly associated with the day of death. ${ }^{14}$ The age indicators, however, do not have significant estimated marginal effects.

Once again, the key variables are the indicator for deceased with estates large enough to be taxable for legal heirs and the indicator for deceased with estates large enough to be taxable for a married spouse. The tax incentives, however, were reversed compared to the previous New Year holiday. During the New Year holiday 2004/05, the first is expected to cause deaths to be postponed because of tax incentives. The second is expected to have no impact as there were no tax incentives to change the timing of death. This is why it is excluded in the most parsimonious specification. The point estimates suggest the likelihood of dying on New Year's Day, rather than on New Year's Eve, is about 10 percentage points higher for those with estates large enough to be taxable for legal heirs compared to the others.

\subsection{Varying the samples}

Table 4 reports some alternatives to the main specifications. The first change concerns excluding from the sample deceased with neither legal heirs nor a spouse.

Our assumption that estates are divided according to the default rules, and the fact that some deceased do not have legal heirs and do not have a spouse, introduces important constraints. As noted in Subsection 3.1, there are 37 deceased in our sample, or 3.3 percent, for which this applies. The consequence is that it is by definition ruled out that any of the indicators for leaving a taxable estate takes any other value than zero for these deceased.

It is clear from the table that restricting the sample in this way accentuates the previously obtained results. The estimated marginal effects increase for the key variables when there are tax incentives to postpone death.

Measurement error is also an issue, in particular for the value of the estate. This is crucial when defining the indicators for taxable estates. It does not matter in practice for very large estates and very small estates, but for borderline cases close to the inheritance tax exemption levels it might be important.

\footnotetext{
${ }^{14}$ We have tried an indicator for written wills and separate variables for employment income, business income, and capital income in this case too without any significant results.
} 


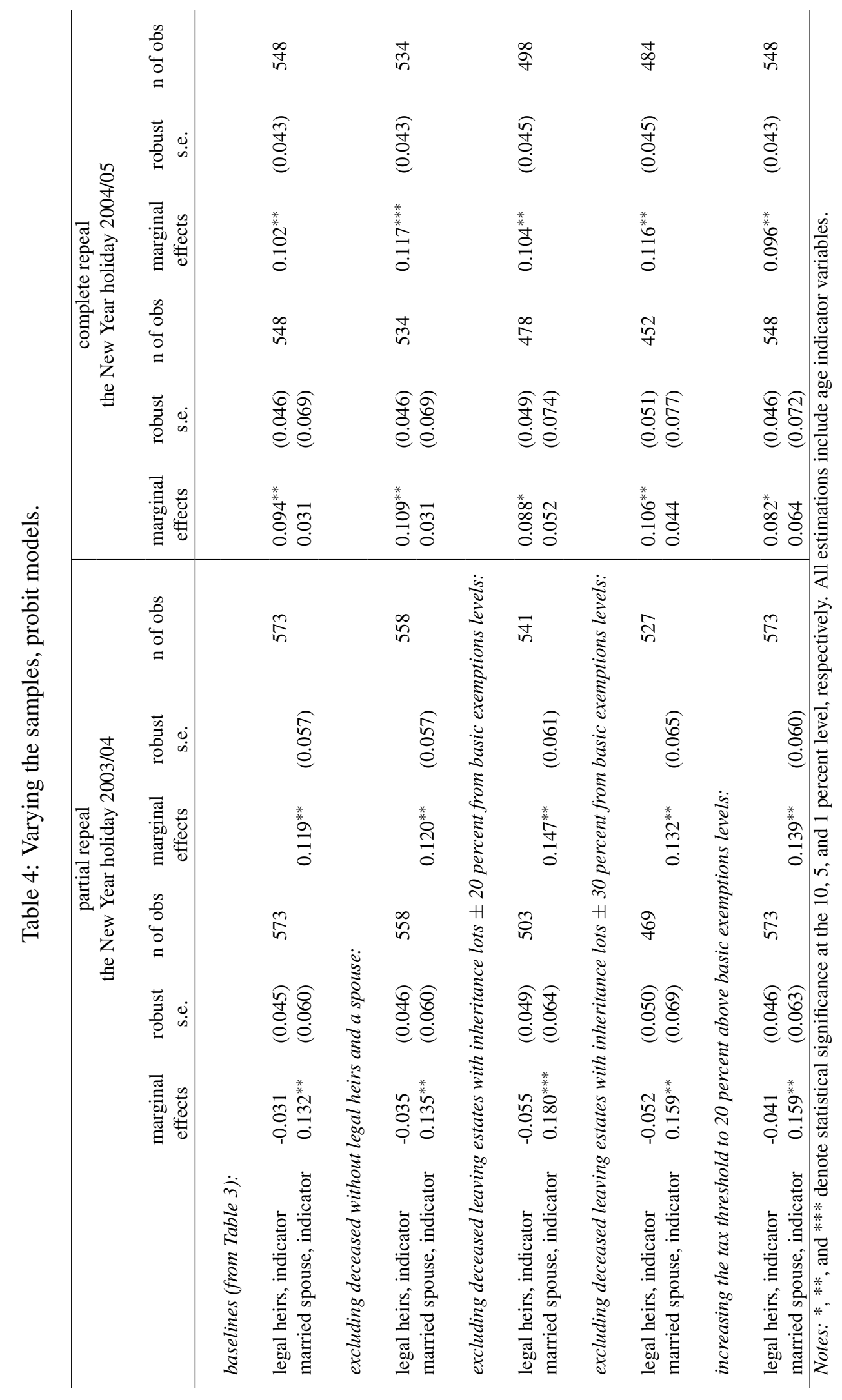


As discussed in Section 3.1, the estate of the first deceased spouse might not have been shifted. Unfortunately, we do not have information enough to adjust the estates for this. Consequently, the estate of the deceased might not be correctly measured. It is also an issue that there are some changes in the principles by which some assets are valued from 2005. Unfortunately, it is in practice very difficult to adjust for this.

Because of these two reasons, our measure of the estate of the deceased might be biased upwards for some. But there might also exist other sources of measurement error biasing our measure of the estate of the deceased downwards. We have, therefore, used a symmetric adjustment for measurement error by simply excluding observations with estate values within an interval around the inheritance tax exemptions levels.

Excluding deceased leaving estates resulting in inheritances \pm 20 percent from basic exemptions levels increases the estimated marginal effects for the key variables for the New Year holiday 2003/04. Increasing the interval to \pm 30 percent decreases the sample size further. The estimated marginal effects become smaller, but are still larger than in the baseline estimations.

The results for the following turn of the year are somewhat different. In this case the estimated marginal effects of the key variables increase when the exclusion interval is increased from \pm 20 percent to \pm 30 percent.

Finally, we have increased the tax threshold to 20 percent above basic exemption levels instead of excluding some estates. This does not, however, alter the results much.

Our conclusion from these sensitivity analyses is that the results are robust to variations of the sample. If anything, the results are accentuated when deceased without legal heirs or a spouse and deceased leaving estates resulting inheritances close to the basic exemption levels are excluded.

\subsection{Varying the tax variables}

We have also tried alternatives to the taxable estate indicators to measure the potential tax saving from postponing death. First, we have calculated the potential tax saving in SEK for an inheritance lot from of each estate. As the estates are equally divided, this tax saving is, in principle, the same for all heirs. Following Kopczuk and Slemrod (2003), we then compute three different measures of the tax saving: the log of the absolute tax saving, the tax saving in relation to the inherited amount, and the absolute tax saving. We also know the marginal inheritance tax rate on the lot as we can calculate the highest tax bracket for the lot. 


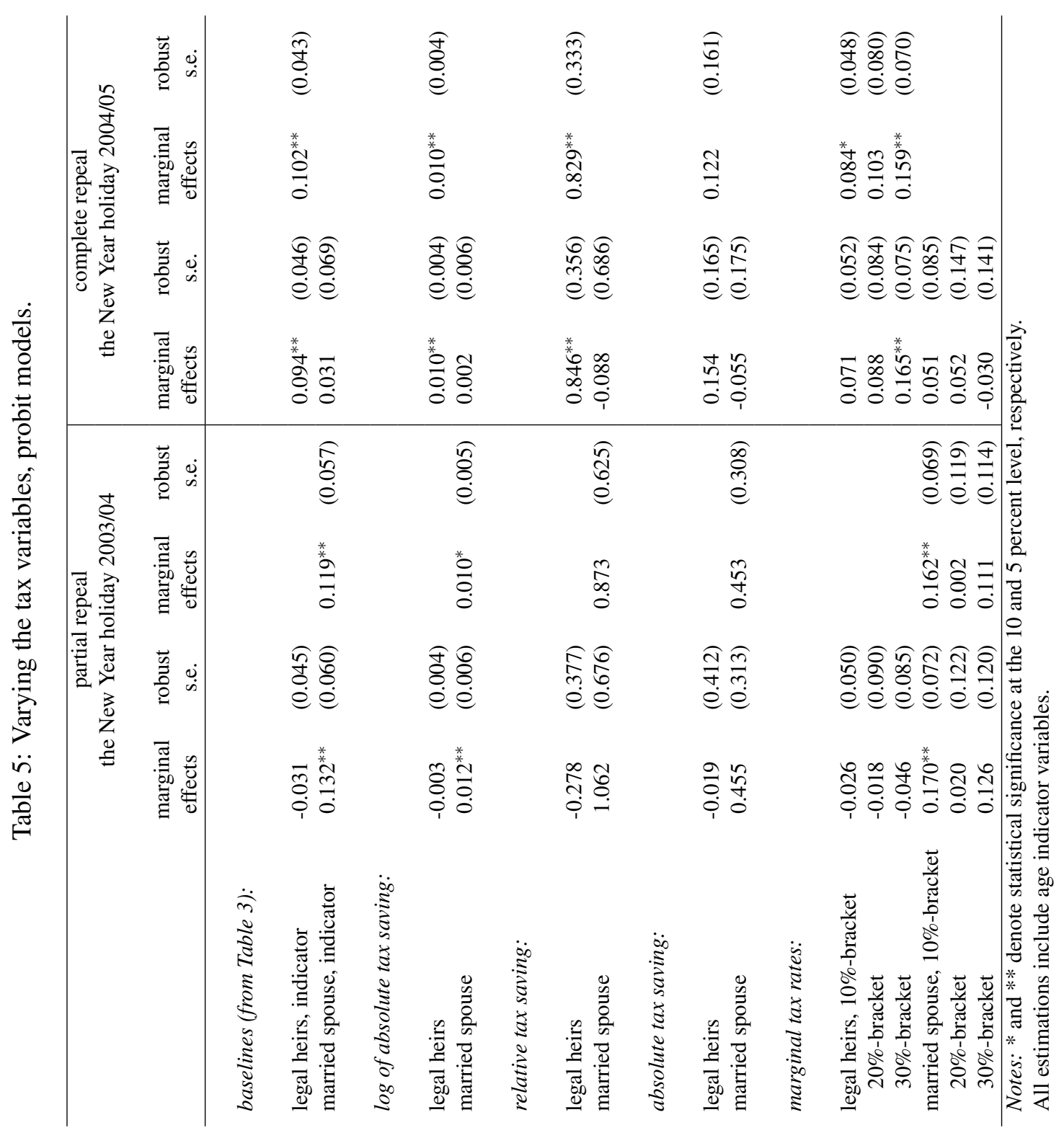


Table 5 reports the estimation results. It is clear from the table that measuring the tax saving as the log of the absolute tax saving yields results similar the baseline results. The marginal effect of the relative tax saving of legal heirs is positive and significant in the models for the New Year holiday 2004/05 with the complete repeal of the inheritance tax. The marginal effect of the absolute tax saving, on the other hand, is not significant in any of the specifications. These qualitative results are in line with the findings of Kopczuk and Slemrod (2003).

Relating the timing of death to the marginal inheritance tax rates also gives some results suggesting a higher marginal tax rates gives a larger behavioral response. It is clear from the table that the estimated marginal effects are higher the higher marginal rates for legal heirs are during the New Year holiday 2004/05. A corresponding relationship is, however, not found the previous New Year for the marginal inheritance tax rates that married spouses faced.

\subsection{Varying the window size}

\section{Framework}

The estimations reported so far are based on data for two days around the tax repeals. The window size is, in other words, \pm 1 day. We have reported significant effects of the tax repeals on the timing of death for those with tax incentives to do so. But this is not to say that we have captured the total effects of the tax repeals. Behavior may have been affected long before and long after the time of the tax repeals.

There is a simple but crucial question to be answered when deciding the window size: From when to when is behavior affected by the policy reform? It might arise difficulties in empirically identifying significant effects if one chooses a too large window. In some cases a too large window may also generate unnecessary data collection efforts.

A too small window, on the other hand, may give rise to what can be called window size bias when one tries to estimate total effects of a policy reform. Let us analyze the window size bias using an illustrative example. Think of a time path with events due. Events may, for instance, be deaths or births. Suppose that is only possible to postpone events due while it is not to possible to advance events due. With postponements there will be another time path of actual events that differ from the time path of events due. In addition, think of an ordinal time scale with six periods:

Period -3 is the time before postponements start. All events due are all materialized into actual events.

Period -2 is the time long before the policy reform. Postponements start during this period. The number of actual events becomes lower than the number of events due. 
Period -1 is the time shortly before the policy reform. Postponements continue during this period. The number of actual events remains lower the number of events due.

Time 0 is the exact time of the policy reform.

Period 1 is the time shortly after the policy reform. The number of actual events becomes higher than the number of events due. Imperfect foresight and crowding out because of capacity constraints may result in additional postponements.

Period 2 is the time long after the policy reform. This period is affected by previous postponements, but there are no new postponements. The number of actual events is higher than the number of events due.

Period 3 is the time when there no longer are any effects of postponements. All actual events are events due during this period.

There are six possible postponements within this framework. Figure 3 shows the possible flows with two different window sizes indicated. There are three possible postponements from period -2 . The first flow, (a), is to period -1 . These postponements are unsuccessful in the sense that the event is materialized before the policy reform. The other two flows are, in the same sense, successful. Flow (b) goes to period 1 while flow (c) goes to period 2.

From period -1, there are two possible flows, both successful. Flow (d) goes to period 1 while flow (e) goes to period 2. Finally, flow (f) captures the postponements after the policy reform from period 1 to period 2 .

Now let us turn to the consequences of the choice of window size within this framework. A window from -3 to 3 is unnecessarily large in the sense that periods unaffected by postponements are included.

How about a window from -1 to 1 ? This is the top alternative of Figure 3. Suppose that we can observe the actual events but that we do not know when these events were due. In addition, suppose that we use the difference of the number of actual events between period -1 and period 1 to estimate the extent of postponement of events due in period -1 . We would, in other words, like to estimate the sum of flows (d) and (e).

There will be four potential sources of window size bias in this case. Flow (a) will create a downward bias, we will have too many events recorded during period -1 as these events were due in period -2 and not in period -1 . Flow (b), on the other hand, will create an upward bias as will have too many events recorded in period 1 as these events were due in period -2 and not in period -1 .

Some postponements of events due in period -1 may end up being materialized in period 2. There will be a downward bias from flow (e), we will record too few postponements. Similarly flow (f) also creates a downward bias.

A sufficient condition for the window size bias to unambiguously be downward is to assume that flow (a) is larger than flow (b). It is not unreasonable to believe that there will be more postponements to a neighboring than to a later period. If 
Figure 3: Window size and possible flows.
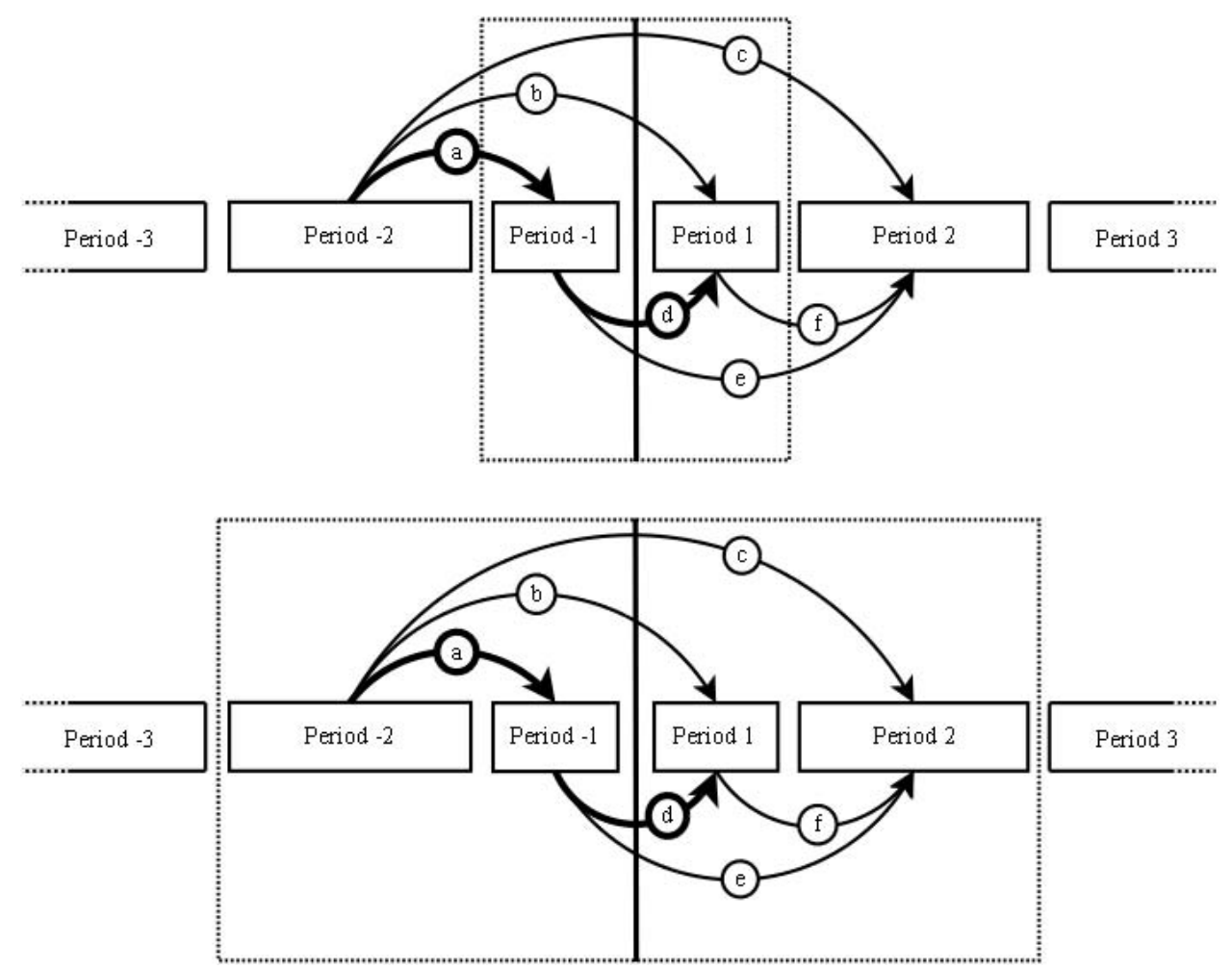
this condition is met for the events we study in this paper, the previously reported significant estimation results may be on the lower side in the sense that not all postponements of births due period -1 are captured.

A window from -2 to 2 is large enough to capture all postponements, see bottom alternative of Figure 3. Suppose that we use the difference in the number of actual events in periods -2 and -1 , taken together, and in periods 1 and 2 , taken together, to estimate the postponement of events due in periods -2 and -1 . We will then capture four flows of successful postponements, (b)-(e). The unsuccessful postponements (a) and the post reform postponements (f) will, on the other hand, each cancel out with a window size large enough.

Our tests

We have collected an extended sample to study the effects of varying the window size. The extended sample consists of adults deceased during the period December 25, 2004-January 7, 2005 and who were born the 5th, the 10th, the 15th, the 20th, or the 25th of the month. All Swedes killed in the Asian Tsunami have December 26, 2004 as their date of death. The 65 Tsunami victims born the above days of the month have been excluded from the extended sample.

Table 6 reports the estimation results. The upper panel contains the results for symmetric windows. The indicators for estates taxable for legal heirs are significant at the 1 percent level for the three largest window sizes. For the largest window, the result is that deceased with estates taxable for legal heirs were almost 15 percentage points more likely to die during the first week of 2005, when the inheritance tax was repealed, rather than during the last week of 2004, compared to deceased without taxable estates for legal heirs. The estimated marginal effect for this window size is larger than for the previous New Year holiday window and the standard error is lower. Suppose that we use the estimated marginal effects are used to calculate predictions of the absolute numbers of successful postponements. It is then clear that the \pm 7 days window predicts many more successful postponements than the \pm 1 day window.

The estimation results can be used to illustrate the effects of varying the window size. We will do this by stepwise narrowing the window. Suppose that the number of successful postponements found for the \pm 7 days window all took place within a smaller \pm 6 days window. (In terms of the illustrative model we go from a $-3-3$ window to a $-2-2$ window.) We would then expect the marginal effect for the \pm 6 days window to be higher than the marginal effect for the \pm 7 days window as we are relating the same number of successful postponements to a smaller number of deaths not postponed. Assuming that the number of deaths due each day is the same, we would expect the \pm 6 days window marginal effect to be higher than the \pm 7 days window marginal effect by a factor $14 / 12 \approx 1.167$.

We have normalized the estimated marginal effects to a fortnight window simply using the number of days of the window. This is reported in the row below the rows with the estimated marginal effects and standard errors. Comparing the normalized marginal effects for the \pm 7 days and \pm 6 days windows, 0.144 and 0.130 , 
Table 6: Varying the window size, deceased the New Year 2005 rather than the Old Year 2004, adults, extended sample, probit models, marginal effects.

\begin{tabular}{lcccccc}
\hline window, days & 7 & 6 & 5 & 4 & 3 & 2 \\
\hline & & & & & & \\
symmetric, \pm window & & & & & & \\
& & & & & & \\
estate taxable for & $0.144^{* * *}$ & $0.152^{* * *}$ & $0.145^{* * *}$ & $0.118^{* *}$ & $0.117^{*}$ & $0.276^{* * *}$ \\
legal heirs, indicator & $(0.040)$ & $(0.043)$ & $(0.048)$ & $(0.053)$ & $(0.064)$ & $(0.082)$ \\
& & & & & & \\
fortnight window normalization & 0.144 & 0.130 & 0.104 & 0.067 & 0.050 & 0.079 \\
& & & & & & \\
n of observations & 627 & 529 & 440 & 365 & 262 & 157 \\
$\begin{array}{l}L R \chi^{2} \\
\text { prob }>\chi^{2}\end{array}$ & 23.02 & 23.14 & 22.52 & 16.92 & 15.13 & 16.94 \\
pseudo $R^{2}$ & 0.0017 & 0.0016 & 0.0021 & 0.0179 & 0.0343 & 0.0178 \\
\hline
\end{tabular}

asymmetric, the last seven days of 2004 fixed, the number of days in January 2005 varies

\begin{tabular}{lcccccc} 
estate taxable for & $0.144^{* * *}$ & $0.156^{* * *}$ & $0.160^{* * *}$ & $0.130^{* * *}$ & $0.130^{* * *}$ & $0.161^{* * *}$ \\
legal heirs, indicator & $(0.040)$ & $(0.041)$ & $(0.043)$ & $(0.044)$ & $(0.044)$ & $(0.041)$ \\
& & & & & & \\
fortnight window normalization & 0.144 & 0.145 & 0.137 & 0.102 & 0.093 & 0.104 \\
& & & & & & \\
n of observations & 627 & 582 & 541 & 503 & 457 & 401 \\
$L R \chi^{2}$ & 23.02 & 23.10 & 22.90 & 16.92 & 18.00 & 22.49 \\
prob $>\chi^{2}$ & 0.0017 & 0.0016 & 0.0018 & 0.0179 & 0.0120 & 0.0021 \\
pseudo $R^{2}$ & 0.0270 & 0.0290 & 0.0309 & 0.0346 & 0.0343 & 0.0592 \\
\hline
\end{tabular}

asymmetric, the first seven days of 2005 fixed, the number of days in December 2004 varies

\begin{tabular}{|c|c|c|c|c|c|c|}
\hline $\begin{array}{l}\text { estate taxable for } \\
\text { legal heirs, indicator }\end{array}$ & $\begin{array}{l}0.144^{* * *} \\
(0.040)\end{array}$ & $\begin{array}{l}0.137^{* * *} \\
(0.042)\end{array}$ & $\begin{array}{l}0.120^{* * *} \\
(0.043)\end{array}$ & $\begin{array}{l}0.112^{* *} \\
(0.044)\end{array}$ & $\begin{array}{r}0.083^{*} \\
(0.044)\end{array}$ & $\begin{array}{l}0.094^{* *} \\
(0.040)\end{array}$ \\
\hline fortnight window normalization & 0.144 & 0.127 & 0.103 & 0.088 & 0.060 & 0.061 \\
\hline $\mathrm{n}$ of observations & 627 & 574 & 526 & 489 & 432 & 383 \\
\hline$L R \chi^{2}$ & 23.02 & 22.96 & 22.42 & 21.07 & 15.13 & 10.20 \\
\hline prob $>\chi^{2}$ & 0.0017 & 0.0017 & 0.0021 & 0.0037 & 0.0343 & 0.1774 \\
\hline pseudo $R^{2}$ & 0.0270 & 0.0292 & 0.0306 & 0.0313 & 0.0412 & 0.0254 \\
\hline
\end{tabular}

Notes. ${ }^{*}, * *$, and $* * *$ denote statistical significance at the 10,5 , and 1 percent level, respectively.

Robust standard errors within parentheses.

All estimations include age indicator variables. 
suggests that not all the action found in the larger window took place within the smaller window. (In terms of the illustrative model it seems that we are going from a $-2-2$ window to a $-1-1$ window.) The normalized marginal effects, however, decrease more going from \pm 6 days to \pm 5 days and from \pm 5 days to \pm 4 days.

There is nothing, however, that requires windows to be symmetric. The middle panel and the lower panel in Table 5 report estimation results for asymmetric windows. The windows in the middle panel all include the last seven days of 2004, while number of included days in January 2005 varies. Looking at the normalized marginal effects suggests that January 6 and January 7 were not affected by postponements as the first three normalized marginal effects are almost the same.

The lower panel reports estimation results for windows always including the first seven days of 2005 while the number of included days in December 2004 is varied. The normalized marginal effects decrease when the window narrows. This suggests that postponements may have been going on as early as December 25, 2004.

\section{Conclusion}

Research shows that economic incentives affect not only the timing of economic decisions but also other events such as childbearing and marriage. Kopczuk and Slemrod (2003), Gans and Leigh (2006), and Eliason and Ohlsson (2008), moreover, find evidence that timing of death responds to changes in inheritance taxes.

In the present paper, we study if the repeal of the Swedish inheritance tax affected the timing of deaths. We find that, first, deceased with estates taxable for legal heirs were 10 percentage points more likely to have died on New Year's Day 2005, from when the inheritance tax was repealed, rather than on the day before, compared to deceased without taxable estates for legal heirs. The second main result is that deceased with estates taxable for the surviving spouse were 12 percentage points more likely to have died on New Year's Day 2004, from when the inheritance tax between spouses was repealed, rather than on the day before, compared to deceased without estates taxable for married spouses. Tax incentives do seem to matter for the timing of death.

There are a number of potential means by which the timing of death might be affected. One is that terminally ill might postpone death by will. Some studies suggest that death is postponed until after symbolically meaningful occasions such as religious holidays, but there is no consensus in the literature. Second, modern medical technology allows physicians to postpone patients' death in many circumstances. An increasing number of deaths are also preceded by medical end-of-life decisions such as whether to withhold or withdraw life support. A third possibility, in cases where the deceased, in fact, died before the turn of the year, is manipulation of death certificates. Although it is not possible for us to determine if and to what extent any of these means have been at work, we can reasonably rule out the possibility that the death deferral effects were driven by factors unrelated to the tax 
incentive and instead related to the fact that the repeal occurred at the turn of the year.

Concerns have been raised that the repeal of the US Federal Estate Tax in 2010 and its resurrection in 2011 may affect medical decision making and imply ethical difficulties for physicians and caregivers (Mendenhall, 2008). Suppose that one accept that the findings in this study, and in those of Kopczuk and Slemrod (2003) and Gans and Leigh (2006), may be driven by changes in actual timing of death and not only reported date of death. It would then suggest that the repeal in 2010 actually may have affected human well-being for quite many. Postponement of death among terminally-ill, either by will or by life-sustaining treatment, for the sake of saving taxes is not a matter of prolonging life but about delaying death. This might cause human suffering not only for the dying but also for his or her next-of-kin. Moreover, if the estate tax is resurrected in 2011 the timing of death might also be affected in the reversed direction. 


\section{Appendix A. The construction of the data set}

We have used The Swedish Death Index 1947-2006 published by The Federation of Swedish Genealogical Societies on DVD to identify the deceased during the New Year holidays 2003/04 and 2004/05. We have also identified those who died December 25, 2004-January 7, 2005, who were born the 5th, the 10th, the 15th, the 20th, and the 25th of the month, and whether they died in the Asian Tsunami.

The estate reports, including the estate inventories, have then been collected from the Swedish Tax Authority's Inheritance Tax Register. This register has information on all estate reports of deceased in Sweden. ${ }^{15}$ The register is freely and openly available on the public computers at the Tax Authority's offices thanks to the Principle of Public Access to Official Records. It should in this context be pointed out that the Personal Data Act, that in different ways restricts the construction and use of electronic data bases, only applies for those alive.

Most variables have been collected from the Inheritance Tax Register. The income data, however, have been collected from the Swedish Tax Authority's Register of Final Tax on Income. This register is also freely and openly available on the public computers.

We have used extensive time to manually extract and punch the following variables from the registers:

- date of death

- name

- personal identity number (gender can be coded from this)

- marital status

- assets, deceased

- separate assets, deceased

- debts, deceased

- separate debts, deceased

- assets, survivor

- separate assets, survivor

- debts, survivor

- separate debts, survivor

- share of estate of first deceased spouse (missing for January 2005)

- indicator if a share of the estate is from first deceased spouse (for January 2005)

- indicator for will

- indicator for married spouse and cohabiting spouse, respectively

- number of children alive

- number of grandchildren (when children are deceased)

- number of lots for grandchildren

- number of parents alive (when there are no children or descendants of children)

\footnotetext{
${ }^{15}$ It has been compulsory to file estate reports since 1734. The Tax Authority is responsible for keeping the register since 2001 .
} 
- number of siblings (when there are no children or descendants of children and one or both parents are deceased)

- number of lots for siblings

- number of nieces/nephews (when they are legal heirs)

- number of lots for nieces/nephews

- number of children of nieces/nephews (when they are legal heirs)

- number of lots for children of nieces/nephews

- number of aunts/uncles (when there are no other legal heirs)

- employment income 2002 (for deceased the New Year holiday 2003/04)

- net business income 2002 (for deceased the New Year holiday 2003/04)

- capital income 2002 (for deceased the New Year holiday 2003/04)

- employment income 2003 (for deceased during the New Year holidays)

- net business income 2003 (for deceased during the New Year holidays)

- capital income 2003 (for deceased during the New Year holidays)

- employment income 2004 (for deceased the New Year holiday 2004/05)

- net business income 2004 (for deceased the New Year holiday 2004/05)

- capital income 2004 (for deceased the New Year holiday 2004/05)

Employment income includes salaries, social insurance system benefits (such as sickness benefits and parental benefits), and unemployment benefits. Costs for commuting to work are deducted. But employment income also includes public pensions and occupational pensions.

We transform income nonlinearly for the estimations to take into account that the income distribution is strongly skewed. The transformation we apply is the so-called inverse hyperbolic sine transformation (Burbidge et al., 1988), which is close to a log transformation but can also accommodate (the few) zeros of the original variable,

$$
z=\sinh ^{-1}(y)=\ln \left(y+\sqrt{y^{2}+1}\right) .
$$

In our data, the approximation is sufficiently close to a log transformation. ${ }^{16} \mathrm{We}$ also transform the tax saving in the same way.

We have not deflated the estate, income, and tax saving variables. The CPI change December 2003-December 2004 was +0.29 percent, the CPI change January $2004-J a n u a r y ~ 2005$ was -0.04 percent. There is no point in deflating as the CPI level was not increasing.

\footnotetext{
${ }^{16} z \approx \ln (2)+\ln (y)$ for $y \geq 2$
} 


\section{References}

Brattström, M. and Singer, A. (2007). Rätt arv: Fördelning av kvarlåtenskap. Iustus Förlag, Uppsala, 2 edition.

Burbidge, J. B., Magee, L., and Robb, A. L. (1988). Alternative transformations to handle extreme values of the dependent variable. Journal of the American Statistical Association, 83(401):123-127.

Donaldson, G. C. and Keatinge, W. R. (2003). Cold related mortality in England and Wales; influence of social class in working and retired age groups. Journal of Epidemiology and Community Health, 57(5):790-791.

Eliason, M. and Ohlsson, H. (2008). Living to save taxes. Economics Letters, 100(3):340-343.

Gans, J. S. and Leigh, A. (2006). Did the death of Australian inheritance taxes affect deaths? B.E. Journals in Economic Analysis and Policy: Topics in Economic Analysis and Policy, 6(1):1-7.

Gans, J. S. and Leigh, A. (2009). The millennium bub. Applied Economics Letters, 16(14):1467-1470.

Idler, E. L. and Kasl, S. V. (1992). Religion, disability, depression, and the timing of death. American Journal of Sociology, 97(4):1052-1079.

Kopczuk, W. and Slemrod, J. (2003). Dying to save taxes: Evidence from estate-tax returns on the death elasticity. Review of Economics and Statistics, 85(2):256265.

Maheswaran, R., Chan, D., Fryers, P., McManus, C., and McCabe, H. (2004). Socio-economic deprivation and excess winter mortality and emergency hospital admissions in the South Yorkshire Coalfields Health Action Zone, UK. Public Health, 118(3):167-176.

McPherson, C. J., Wilson, K. G., and Murray, M. A. (2007). Feeling like a burden to others: A systematic review focusing on the end of life. Palliative Medicine, 21(2):115-128.

Mendenhall, G. S. (2008). Death and taxes. Annals of Internal Medicine, 149(11):822-824.

Miccinesi, G., Fischer, S., Paci, E., Onwuteaka-Philipsen, B. D., Cartwright, C., van der Heide, A., Nilstun, T., Norup, M., and Mortier, F. (2005). Physicians' attitudes towards end-of-life decisions: a comparison between seven countries. Social Science \& Medicine, 60(9):1961-1974. 
Panesar, N. S. and Goggins, W. (2009). Postponement of death around Chinese holidays: A Hong Kong perspective. Singapore Medical Journal, 50(10):990996.

Phillips, D. and Smith, D. (1990). Postponement of death until symbolically meaningful occasions. JAMA, 263(14):1947-1951.

Phillips, D. P. and King, E. W. (1988). Death takes a holiday: Mortality surrounding major social occasions. Lancet, 332(8613):728-732.

Rau, R. (2004). Lack of social gradient in winter excess mortality is obvious in Denmark. British Medical Journal, 329(7472):976-977.

Rocklöv, J. and Forsberg, B. (2008). The effect of temperature on mortality in Stockholm 1998-2003: A study of lag structure and heatwave effects. Scandinavian Journal of Public Health, 36(5):516-523.

Shimizu, M. and Pelham, B. W. (2008). Postponing a date with the grim reaper: Ceremonial events and mortality. Basic and Applied Social Psychology, 30(1):36-45.

Smith, G. (2004). Asian-American deaths near the Harvest Moon Festival. Psychosomatic Medicine, 66(3):378-381.

SOU (2001). Döden angår oss alla - värdig vård vid livets slut. SOU 2001:6. Fritzes, Stockholm.

Tseng, S. H. (2004). The effect of life insurance policy provisions on suicide rates. Working paper, University of Chicago.

van der Heide, A., Deliens, L., Faisst, K., Nilstun, T., Norup, M., Paci, E., van der Wal, G., and van der Maas, P. J. (2003). End-of-life decision-making in six European countries: descriptive study. Lancet, 362(9381):345-350.

Waller, E. (2000). AGL: Lärobok om arvs- och gåvoskatt. Iustis Förlag, Uppsala, 5 edition.

Young, D. C. and Hade, E. M. (2004). Holidays, birthdays, and postponement of cancer death. JAMA, 292(24):378-381. 
WORKING PAPERS*

Editor: Nils Gottfries

2008:13 Matz Dahlberg, Kajsa Johansson and Eva Mörk, On mandatory activation of welfare receivers. 39pp.

2008:14 Magnus Gustavsson, A Longitudinal Analysis of Within-Education-Group Earnings Inequality. 26pp.

2008:15 Henrique S. Basso, Delegation, Time Inconsistency and Sustainable Equilibrium. 24pp.

2008:16 Sören Blomquist and Håkan Selin, Hourly Wage Rate and Taxable Labor Income Responsiveness to Changes in Marginal Tax Rates. 31 pp.

2008:17 Jie Chen and Aiyong Zhu, The relationship between housing investment and economic growth in China : A panel analysis using quarterly provincial data. 26pp.

2009:1 Per Engström, Patrik Hesselius and Bertil Holmlund, Vacancy Referrals, Job Search, and the Duration of Unemployment: A Randomized Experiment. 25 pp.

2009:2 Chuan-Zhong Li and Gunnar Isacsson, Valuing urban accessibility and air quality in Sweden: A regional welfare analysis. 24pp.

2009:3 Luca Micheletto, Optimal nonlinear redistributive taxation and public good provision in an economy with Veblen effects. $26 \mathrm{pp}$.

2009:4 Håkan Selin, The Rise in Female Employment and the Role of Tax Incentives. An Empirical Analysis of the Swedish Individual Tax Reform of 1971. 38 pp.

2009:5 Lars M. Johansson and Jan Pettersson, Tied Aid, Trade-Facilitating Aid or Trade-Diverting Aid? 47pp.

2009:6 Håkan Selin, Marginal tax rates and tax-favoured pension savings of the selfemployed Evidence from Sweden. 32pp.

2009:7 Tobias Lindhe and Jan Södersten, Dividend taxation, share repurchases and the equity trap. 27pp.

2009:8 Che-Yuan Liang, Nonparametric Structural Estimation of Labor Supply in the Presence of Censoring. 48pp.

2009:9 Bertil Holmlund, Incentives in Business and Academia. 12pp.

\footnotetext{
* A list of papers in this series from earlier years will be sent on request by the department.
} 
2009:10 Jakob Winstrand, The Effects of a Refinery on Property Values - The Case of Sweden. 27pp.

2009:11 Ranjula Bali Swain and Adel Varghese, The Impact of Skill Development and Human Capital Training on Self Help Groups. 28pp.

2009:12 Mikael Elinder. Correcting Mistakes: Cognitive Dissonance and Political Attitudes in Sweden and the United States. 25 pp.

2009:13 Sören Blomquist, Vidar Christiansen and Luca Micheletto: Public Provision of Private Goods and Nondistortionary Marginal Tax Rates: Some further Results. 41pp.

2009:14 Mattias Nordin, The effect of information on voting behavior. 34pp.

2009:15 Anders Klevmarken, Olle Grünewald and Henrik Allansson, A new consumer price index that incorporates housing. $27 \mathrm{pp}$.

2009:16 Heléne L. Nilsson, How Local are Local Governments? Heterogeneous Effects of Intergovernmental Grants. 41pp.

2009:17 Olof Åslund, Per-Anders Edin, Peter Fredriksson and Hans Grönqvist, Peers, neighborhoods and immigrant student achievement - evidence from a placement policy. $27 \mathrm{pp}$.

2009:18 Yunus Aksoy, Henrique S. Basso and Javier Coto-Martinez, Lending Relationships and Monetary Policy. 42 pp.

2009:19 Johan Söderberg, Non-uniform staggered prices and output persistence. $38 \mathrm{pp}$.

2010:1 Jonathan Gemus, College Achievement and Earnings. 43 pp.

2010:2 Susanne Ek and Bertil Holmlund, Family Job Search, Wage Bargaining, and Optimal Unemployment Insurance. 30 pp.

2010:3 Sören Blomquist and Laurent Simula, Marginal Deadweight Loss when the Income Tax is Nonlinear. 21 pp.

2010:4 Niklas Bengtsson, The marginal propensity to earn, consume and save out of unearned income in South Africa. $34 \mathrm{pp}$.

2010:5 Marcus Eliason and Henry Ohlsson, Timing of death and the repeal of the Swedish inheritance tax. 29 pp.

See also working papers published by the Office of Labour Market Policy Evaluation http://www.ifau.se/

ISSN 1653-6975 